\title{
HATÉKONY PEDAGÓGUSOK - MI A TITKUK?
}

Ezzel a figyelemfelhívó, kíváncsiságot ébresztő címmel indult útjára 2006-ban, a Pedagógusképzés folyóiratban az akkor születő rovat. Életre hívója Hunyady Györgyné $d r$. a rovat céljaként jelölte meg, hogy jelentős pedagógusszemélyiségeket tanítványaik emlékeinek tükrében mutat meg Olvasóinak.

A tanítványok perspektíváján keresztül, kaleidoszkópba pillantva láthatjuk meg eleven képek segítségével a szeretett, tisztelt pedagógus személyét. Ez a fajta világokba való betekintés mérőmüszereknél pontosabban érzékelteti, mi is a jelentős pedagógusok hatékonyságának titka. Külön értéke az írásoknak, a szerzők és az emlékeikben megjelenő pedagógus különleges, személyes kapcsolata. Hiszen a nevelés és oktatás olyan, hivatástudattal vállalható feladat, amely hatékonyságának lényege a személyes kapcsolat. Az időálló emberi, pedagógusi értékek felmutatása mellett, azoknak a pedagógusoknak is sokat nyújthat ez a rovat, akik életpályájukra rátekintve meglátják, milyen hatással vannak a mindennapi pedagógiai gyakorlatra, milyen hatással vannak a közoktatásra.

A rovat indulásakor a legeslegelső írás Nagy Sándorról született, tanítványa $M$. Nádasi Mária tollából. Különlegessége ennek a számnak, hogy tíz kerek év elteltével M. Nádasi Mária tanítványai kutatják tovább a pedagógiai hatékonyság titkát.

Az arcképvázlat szerzöjének személyes kapcsolata vagy éppen valamilyen egyéni kötődése van az arcképcsarnokban szereplő személlyel. A nevelés és oktatás máshoz nem hasonlítható hivatástudattal vállalható feladat. Aki szívvel-lélekkel végzi a munkáját, az dolgozik jól. Valaha úgy mondták: hittel, lélekkel, s a szólásnak valós tartalma volt: a hit erőt adott a legnehezebb feladatok vállalásához, végzéséhez. Remélem, minden emlékezés megmutatja, hogy hatékony iskola, hatékony közoktatás a pedagógus egyéniségek munkáján keresztül bontakozhat ki.

Rendkívül érdekes, hogy Nádasi Máriának milyen nagy hatása volt a történeti helyzet okán arra, hogy a közoktatást formálja. Az 1989 után alapított alternatív iskolákban elhelyezkedő pedagógusok nagy része Tőle kapta a lendületet, az inspirációt, a tudást. 